\title{
Librarians' Perceptions of the Reference Interview
}

\author{
Michelle L. Eberle
}

\begin{abstract}
This article identifies librarians' perceptions of challenges providing reference services in the context of mental health. The reference interview will be discussed in context of mental health questions. Topics discussed include the reference interview process, ethics and barriers to information access and challenges of the reference interview. The information included in the article is based on discussions held at $\mathrm{Na}-$ tional Network of Libraries of Medicine, New England Region consumer health classes held in 2004. [Article copies available for a fee from The Haworth Document Delivery Service: 1-800-HAWORTH. E-mail address: $<$ docdelivery@haworthpress.com>Website: <http://www.HaworthPress.com> (C) 2005 by The Haworth Press, Inc. All rights reserved.]
\end{abstract}

KEYWORDS. Reference interview, perceptions, mental health, ethics, barriers to information access, collection development

\section{INTRODUCTION}

The reference interview is essential to meeting the information needs of library patrons. Many factors enter into a successful reference interview including the librarian's communication style, the patron's emotions and literacy skills, and the resources available. This article seeks to

Michelle L. Eberle is Consumer Health Information Coordinator, National Network of Libraries of Medicine, New England Region, Massachusetts Medical School's Lamar Soutter Library (E-mail: michelle.eberle@umassmed.edu).

Journal of Hospital Librarianship, Vol. 5(3) 2005

Available online at http://www.haworthpress.com/web/JHSPL

(c) 2005 by The Haworth Press, Inc. All rights reserved.

doi:10.1300/J186v05n03_03 
identify librarians' perceptions of challenges providing reference services in the context of mental health. Also included are suggestions for improving reference services and a discussion of the reference interview process, ethical aspects, and barriers to information access.

\section{COLLECTION OF PERCEPTIONS}

The perceptions of librarians included in this article are taken from class discussions about the reference interview conducted with public, academic, and medical librarians at presentations of the Medical Library Association approved course, "Caring for the Mind: Providing Reference Services for Mental Health Information." This course was taught by the author five times during the fall of 2004. Also included are responses from a presentation of "Reference Rx: From the Trenches" which was presented at the New England Library Association in the fall of 2004 and from presentations in 2004 of "Beyond an Apple a Day: Developing a Consumer Health Information Program.” Approximately one hundred fifty librarians attended the presentations.

\section{Questions Raised}

At each presentation, librarians were asked to respond to the following questions:

1. What challenges face librarians during reference interviews?

2. How can librarians improve reference services?

\section{Summary of Responses}

When analyzed, responses from the classes tended to fall into three themes.

1. The Reference Interview Process

2. Ethics

3. Barriers to Information Access (Table 1)

\section{THE REFERENCE INTERVIEW PROCESS}

The main challenge that librarians shared was how to identify the patrons' needs for mental health information and provide appropriate re- 
TABLE 1. Summary of Responses

\begin{tabular}{|c|c|c|}
\hline THEME & COMMENTS & TIPS \\
\hline \multirow[t]{7}{*}{$\begin{array}{l}\text { Reference Interview } \\
\text { Process }\end{array}$} & "Get to what it is the patrons wants!" & $\begin{array}{l}\text { - Use open-ended questions } \\
\text { - Active listening }\end{array}$ \\
\hline & $\begin{array}{l}\text { "How do I determine how much } \\
\text { information is needed, the level of } \\
\text { understanding, when to leave the } \\
\text { patron with the information and let } \\
\text { them research on his or her own?" }\end{array}$ & $\begin{array}{l}\text { - Active listening } \\
\text { - Follow steps of a reference } \\
\text { interview as outlines in } \\
\text { Healthlnfoquest (2) }\end{array}$ \\
\hline & $\begin{array}{l}\text { "be able to ask more appropriate } \\
\text { questions." }\end{array}$ & $\begin{array}{l}\text { - Select a set of three open-ended } \\
\text { questions and integrate them into } \\
\text { your reference interviews }\end{array}$ \\
\hline & $\begin{array}{l}\text { "A patron may not have terminology } \\
\text { or the complete diagnosis correct." }\end{array}$ & $\begin{array}{l}\text { - Have a print medical dictionary at } \\
\text { the reference desk } \\
\text { - Familiarize yourself with some } \\
\text { online medical dictionaries }\end{array}$ \\
\hline & $\begin{array}{l}\text { "trying to determine the level of } \\
\text { comfort a patron might have with } \\
\text { medical language. Do they really } \\
\text { understand what they have been } \\
\text { given in answer to their question } \\
\text { about the drug they are taking?" }\end{array}$ & $\begin{array}{l}\text { - Be sensitive to health literacy } \\
\text { during collection development } \\
\text { - Be prepared to provide } \\
\text { easy-to-read resources in both } \\
\text { print and electronic format }\end{array}$ \\
\hline & $\begin{array}{l}\text { "Familiarizing ourselves with } \\
\text { available resources and the level } \\
\text { of difficulty of each." }\end{array}$ & $\begin{array}{l}\text { - Be aware of core lists for health } \\
\text { information } \\
\text { - Know how to check the literacy } \\
\text { level of a resource }\end{array}$ \\
\hline & $\begin{array}{l}\text { "A patron may be there to find } \\
\text { something to do to fill time. It is } \\
\text { difficult if you are busy at the desk } \\
\text { with other patrons." }\end{array}$ & $\begin{array}{l}\text { - Have a plan in place for such a } \\
\text { patron. }\end{array}$ \\
\hline \multirow[t]{3}{*}{ Ethics } & $\begin{array}{l}\text { "We really don't want to know } \\
\text { someone's personal medical issues, } \\
\text { yet we need to know what to search." }\end{array}$ & $\begin{array}{l}\text { - Use open-ended questions } \\
\text { - Respect confidentiality }\end{array}$ \\
\hline & $\begin{array}{l}\text { "be removed enough to conduct a } \\
\text { good search." }\end{array}$ & $\begin{array}{l}\text { - Do not offer advice or share } \\
\text { anecdotes from your own medical } \\
\text { history }\end{array}$ \\
\hline & $\begin{array}{l}\text { "It is important to clarify what you as } \\
\text { librarian can and cannot do, to be } \\
\text { able to explain your role as someone } \\
\text { who will help them find information } \\
\text { not as a counselor." }\end{array}$ & $\begin{array}{l}\text { - Be familiar with the CAPHIS Role } \\
\text { of the Librarian in the Provision } \\
\text { of Consumer Health \& Patient } \\
\text { Education }\end{array}$ \\
\hline $\begin{array}{l}\text { Barriers to Information } \\
\text { Access }\end{array}$ & $\begin{array}{l}\text { "The stigma issue-people are } \\
\text { reluctant to talk about this sort of stuff } \\
\text { and they may not be specific about } \\
\text { what they really want to know." }\end{array}$ & $\begin{array}{l}\text { - Be aware of the reluctance to ask } \\
\text { for assistance of persons with } \\
\text { certain stigmatized medical } \\
\text { conditions }\end{array}$ \\
\hline
\end{tabular}

sources. Discussion with librarians at the classes confirmed that a reference interview should follow a standard procedure regardless of the nature of the question. A question for mental health information should not be treated differently from any other reference question. Likewise, a patron with a mental illness should be treated with the same courtesy as any other patron. 
The process of the reference interview was identified by one librarian as a concern. She shared, "How do I determine how much information is needed, the level of understanding, when to leave the patron with the information and let them research on his or her own?" Another concern was how to "get at what it is the patron wants!" Repeatedly, class participants emphasized the importance of active listening. A patron shared that listening carefully allowed her to "be able to ask more appropriate questions."

An excellent way to get to the root of what the patron really wants is by asking open-ended and neutral questions. Being equipped with a selection of at least three open-ended questions helps a librarian to probe to the core of a patron's information needs. A list of open-ended questions is available by from the InfoPeople Project supported by the U.S. Institute of Museum and Library Services (1). An open-ended question cannot be answered by yes or no. Open-ended questions usually begin with who, what, where, or why. Some examples of open-ended questions include: "What kind of information on know?" and "Would you tell me more about. ..." would you like to

The Pacific Northwest Region of the National Network of Libraries of Medicine created HealthInfoquest, a pathfinder guide to learning how to research health information. HealthInfoquest has a reference interview resource section with information good to review for librarians of all levels of expertise. HealthInfoquest includes examples of health reference interviews for questions about news information and sensitive type questions. Each section of HealthInfoquest recommends following a standard five step procedure including:

- Get the Facts

- Clarify

- Verify

- Follow-up

- Closure (2)

Librarians and patrons both struggle with the complexities of medical terminology. One librarian shared, "A patron may not have terminology or the complete diagnosis correct." Many librarians, particularly public librarians, echoed this concern about identifying the correct spelling of a condition or drug. Since patrons often have incomplete information or incorrect spelling. One public librarian shared the story of a patron who asked for information about metamorphoses. The librarian responded, "Are you looking for Ovid's Metamorphoses?" The patron 
responded, "No, I am looking for information on cancer." The librarian inquired if the patron was seeking information on metastasis or the movement or spreading of cancer cells from one organ or tissue to another. The patron said, "Oh yes, that's it." This story is a good example of how incorrect terminology completely changes the exchange of information.

Most medical librarians have access to several excellent medical dictionaries in which to look up complex medical terminology. For those librarians without a current medical dictionary, the National Library of Medicine's MedlinePlus ${ }^{\circledR}$ has a free online medical dictionary provided by Merriam Webster (3). YourDictionary.com has a list of specialty dictionaries, including online versions of Stedman's Medical Dictionary and Dorland's Illustrated Medical Dictionary. YourDictionary.com also features a multilingual glossary of medical terms and glossaries of terms on specific health conditions (4).

Many librarians were concerned with the issue of health literacy. One librarian shared the importance of, "trying to determine the level of comfort a patron might have with medical language. Do they really understand what they have been given in answer to their question about the drug they are taking?" Other librarians shared the importance of "familiarizing ourselves with available resources and the level of difficulty of each."

In Healthy People 2010, the U.S. Department of Health and Human Services defines health literacy as:

The degree to which individuals have the capacity to obtain, process, and understand basic health information and services needed to make appropriate health decisions. (5)

The current estimates of health literacy levels in the United States are based on the 1992 National Adult Literacy Survey (NALS). The results of NALS showed that 90 million people, or 48 percent of the United States population, are considered to have limited literacy skills (6). What does this mean for librarians providing health information? Librarians have an important role in providing health information which patrons can comprehend. Librarians should be sensitive to health literacy when selecting new resources for the library. Since there are limited easy to read resources on many topics, familiarity with the Fry Readability Formula is essential in order to identify the literacy level of resources (7). Another role for the librarian is to have information on community resources for Adult Basic Education available for patrons. 
Overall, it is still quite difficult to find easy to read information on less common mental illnesses. Librarians should be aware of easy to read Web resources. The easy to read page on MedlinePlus is still a relatively new resource as it was first compiled in the fall of 2003. The MedlinePlus easy to read page includes Web pages on alcoholism, ADD, bipolar disorder, depression, and panic disorder (3). Some of these pages link to easy to read booklets in both English and Spanish from the National Institute of Mental Health. Other pages link to the MedlinePlus Interactive Tutorials.

The "How to Write Easy to Read Health Materials" page on MedlinePlus is a good resource for librarians to share with their Patient Education Committees (8). Additionally, the health topics section of MedlinePlus serves as an excellent introductory source to over 650 health topics in both English and Spanish (3). An excellent source for easy to read online information about Alzheimer's Disease is the NIH Senior Health site (9). This site includes brief videos on various health topics for seniors.

Participants in the classes inquired about how to handle patrons who tended to monopolize a librarian's time. A medical librarian shared that, "A patron may be there to find something to do to fill time. It is difficult if you are busy at the desk with other patrons."

The class instructor presented two options. Being empathetic and listening is an act of kindness to a patron who may not have a strong social network. However, if a librarian is busy with other patrons, a librarian must set clear limits with demanding patrons. For example, at the New England Library Association Conference, a public librarian shared a plan the librarians at their library developed for a difficult patron. This particular patron called their library every day and asked the same question. The patron became upset if she didn't get the same information every day. Finally, the librarian realized that the patron was seeking consistency. The librarians prepared an information script that they keep on hand to use each day the patron calls. The patron was pleased to receive consistent information each day.

That comments about the process of the reference interview for mental health information are similar to a reference interview for any health information topic implies that the process of a reference interview does not differ when the information is focused on mental health. The importance of this is that when conducting a reference interview with a person with mental illness it is good to follow a standard procedure and not be flustered by the fact that the patron has a mental illness. No two refer- 
ence interviews are exactly alike. Being flexible, responsive, and an active listener will assist with each step of the reference interview.

\section{ETHICS}

Ethical issues always play a role in the provision of reference services. The ethical challenges of the reference interview identified by librarians included protecting confidentiality and providing unbiased information. Librarians were concerned with being sensitive to a patron's privacy. Knowing how much to ask was a concern. The use of open-ended questions is a safe way to investigate further with out being too nosy about a particular issue. A medical librarian shared, "We don't really want to know someone's personal medical issues, yet we need to know what to search." A public librarian similarly stated how important it is to "be removed enough to conduct a good search."

The participants identified understanding the role of the librarian in the reference interview as essential. A medical librarian said, "It is important to clarify what you as a librarian can and cannot do and to explain that a librarian's role is not that of a counselor but someone who will help them find information." Patrons with mental illness may be nervous, stressed, or agitated and emotional states could promote unreasonable expectations of the librarian.

When providing health information, the librarian should refrain from interpreting health information and from sharing personal experiences. The importance of providing unbiased information was emphasized by librarians attending the classes. Public librarians found this issue particularly challenging. Medical librarians, more accustomed to providing health information, seemed more comfortable with this issue. Another point made by one of the class participants was that patrons may not be aware of the potential impact or seriousness of a particular diagnosis. Health concerns are often life altering or life endangering by nature. This issue addresses the importance of being sensitive to the nature of each question and respecting confidentiality. A patron with a new diagnosis may be emotional when trying to convey their information needs. To be sensitive to a patron's privacy, a librarian might offer to consult the patron in a private area or lower his or her voice to respect the patron's confidentiality.

In Consumer Health: An Online Manual, Jana Lieberman suggests tips for librarians striving to provide ethical reference services (10). She recommends the following tips: 
- Respect confidentiality and be sensitive

- Know and express the limits of your collection

- Provide unbiased information

- Refer patrons back to their health professional when appropriate

- Use a disclaimer on resources borrowed from the library

Librarians should be aware of the implications of the provision of ethical reference services. The Role of the Provision of Consumer Health Information and Patient Education, The Consumer and Patient Health Information Section (CAPHIS) of the Medical Library Association's policy statement, serves as a nice introduction to ethics and the role of the librarian (11). The quality of reference service provided may affect the quality of a patron's personal or work life as well as their health. For example, if the confidentiality of a reference question for a chronic mental illness is not kept, a patron's relationships may be altered dramatically. If a librarian provides personal anecdotes, the patron may be provided with misinformation which might have serious health consequences.

\section{BARRIERS TO INFORMATION ACCESS}

The reluctance to ask mental health reference questions was identified as a top barrier to information access for persons with mental health conditions and other stigmatized health conditions such as sexually transmitted diseases. An academic medical librarian shared, "The stigma issue-people are reluctant to talk about this sort of stuff and they may not be specific about what they really want to know."

The prevalence of stigma with certain health conditions means librarians should prepare their collections for ease of accessibility. A patron may be too embarrassed to ask for help, but may desperately need information. During one class, there was a lot of discussion concerning providing consumers a private area to conduct searches.

Librarians were concerned about dealing with difficult patrons. Many librarians shared stories of patrons who were emotional during reference interviews making communication and the provision of information a challenge. Persons with mental illness could be psychotic, manic, or depressed, possibly leading to an tense situation in the library. The Concise Guide to Assessment and Management of Violent Patients outlines steps which could be applied to any situation where inappropriate 
behaviors are escalating (12). The following tips may help deescalate increasingly tense situations:

- Present a calm appearance.

- Speak softly.

- Speak in a non-provocative and nonjudgmental manner.

- Speak in a neutral concrete manner.

- Put space between yourself and the patient.

- Show respect for the patient.

- Avoid intense eye contact and authoritarian stance.

- Facilitate the patient's talking.

- Listen to the patient.

- Avoid early interpretation.

- Do not make promises you cannot keep.

Librarians need to be comfortable providing information for diverse populations. A common stereotype of persons with mental illness reinforced by the media is that they have a tendency towards violence. The view that persons with mental illness are more dangerous is inaccurate. The U.S. Surgeon General Report on Mental Health reports the following on the likelihood of violence by persons with mental illness.

This finding begs yet another question: Are people with mental disorders truly more violent? Research supports some public concerns, but the overall likelihood of violence is low. The greatest risk of violence is from those who have dual diagnoses, i.e., individuals who have a mental disorder as well as a substance abuse disorder (Swanson, 1994; Eronen et al., 1998; Steadman et al., 1998). There is a small elevation in risk of violence from individuals with severe mental disorders (e.g., psychosis), especially if they are noncompliant with their medication (Eronen et al., 1998; Swartz et al., 1998). Yet the risk of violence is much less for a stranger than for a family member or person who is known to the person with mental illness (Eronen et al., 1998). In fact, there is very little risk of violence or harm to a stranger from casual contact with an individual who has a mental disorder. Because the average person is ill-equipped to judge whether someone who is behaving erratically has any of these disorders, alone or in combination, the natural tendency is to be wary. Yet, to put this all in perspective, the overall contribution of mental disorders to the to- 
tal level of violence in society is exceptionally small (Swanson, 1994). (13)

\section{COLLECTION DEVELOPMENT RESOURCES}

Public librarians in particular lack adequate resources to respond to mental health questions. To address this issue, public librarians may develop a relationship with a local medical librarian to share resources. Librarians at the classes identified the importance of being aware of current resources including information on local social services. Some libraries have pamphlets with information about local National Alliance for the Mentally Ill (NAMI) chapter meetings available for their patrons.

Librarians felt that familiarity with common health concerns and resources was key to success. In the winter of 2004, before writing the script for the class, "Caring for the Mind: Providing Reference Services for Mental Health Information," the author conducted an informal survey of librarians on the CAPHIS listserv to identify the most frequently asked mental health questions (14). The following were identified by respondents as the most frequently asked mental health questions:

- Anger Management

- Anxiety

- Asperger's syndrome

- Autism

- Bipolar Disorder

- Borderline Personality Disorder

- Building self-esteem

- Community re-entry

- Depression

- Eating disorders

- Family support
- Health care coverage for the uninsured

- Medication and side effects

- PTSD

- Refusal to take medication

- Relaxation Techniques

- Schizophrenia

- Self-Abuse

- Social Services

- Teenage suicide

\section{RESOURCES FOR COLLECTION DEVELOPMENT}

The following are recommended as sources for collection development to aid in responding to consumer health reference questions for mental health information. Judith Kronick from Healthnet: The Connecticut Consumer Health Information Network created a Web resource 
Mental Health Resources: A Guide for Patients Families (15). This guide provides recommendations for Internet resources as well as books and pamphlets about mental health. Another excellent source for mental health resources is a recent article published by Mary Ellen Hughes in Library Journal in 2004. This article, The Two Faces of Mental Illness, lists important resources on bipolar disorder and schizophrenia (16). The McMaster Children's Hospital in Hamilton, Ontario created resource lists for parents on common behavioral and emotional conditions of children and teens. The resources on their lists are available at their consumer health library and are cross-referenced for availability at the local public library (17). Cross-referencing consumer health resources with your local public library's resources is a great way to partner with your local public library on collection development.

\section{LIMITATIONS AND CONCLUSIONS}

Reference skills may be fine tuned by learning about other librarians' typical experiences and perceptions with providing reference services. Limitations of this article include that the comments are based on discussions which are not scientific by nature. The value of the comments are that librarians may learn from each other's collective experiences and gain a better understanding of how patrons can be better served by our libraries. Findings from the perceptions of librarians who attended National Network of Libraries of Medicine, New England Region consumer health classes in 2004 are the following.

- A reference interview for mental health information should follow the same steps as any other reference interview.

- Patrons may be more reluctant to ask certain types of reference questions.

- To better serve patrons with stigmatized health conditions, librarians must be aware of placement of resources in the library and be sensitive to the specialized needs of underserved populations in the provision of reference services.

The lessons shared by librarians in this article are intended to prompt a heightened awareness of provision of reference service in the context of mental health information. Since all reference interviews are alike, a reference interview for mental health information should not be stifling. Awareness of the delicate and often stigmatized nature of mental health 
information will help a librarian to be more sensitive and empathetic during a reference interview with a patron with mental illness. Developing appropriate collections and being prepared to respond to a variety of situations with patrons will assist librarian-patron communication. In summary, librarians can provide quality reference skills by learning from each others experiences.

Received: January 14, 2005

Revised: February 18, 2005

Accepted: February 21, 2005

\section{REFERENCES}

1. Leita C. (2002). The Reference interview: asking all the right questions. http://www.infopeople.org/training/past/2002/ref_interview/Open-endedQuestions. pdf. (4 Jan 2005).

2. National Network of Libraries of Medicine. (2003). HealthInfoquest: pathfinders to common consumer health questions. http://nnlm.gov/healthinfoquest/. (19 Dec 2004).

3. National Library of Medicine. (2005). MEDLINEPlus. http://medlineplus.gov. (13 Jan 2005).

4. YourDictionary.com. (2004). YourDictionary.com Customizable Dictionary. http://www.yourdictionary.com/diction5.html\#Medicine. (5 Jan 2005).

5. United States Department of Health and Human Services. (2000). Healthy People 2010: Understanding and Improving Health. http://odphp.osophs.dhhs.gov/projects/ HealthComm/objective2.htm. (5 Jan 2005).

6. Kirsch IS, Jungeblut A, Jenkins L, Kolstad A. (1993). Adult literacy in America: a first look at the results of the National Adult Literacy Survey. Washington DC: Department of Education. http://nces.ed.gov/naa/resources/execsumm.asp. (5 Jan 2005).

7. Center for Disease Control: OSPTT. (2001). The Fry Readability Scale. http:// www.cdc.gov/od/ads/fry.htmv. (10 Jan 2004).

8. National Library of Medicine. (2004). How to Write Easy to Read Health Materials. http://www.nlm.nih.gov/medlineplus/etr.html. (7 Jan 2005).

9. National Institutes of Health. (2004). NIH Senior Health. http://www. nihseniorhealth.gov. (13 Jan 2005).

10. Lieberman J. (2000). Ethics and the Consumer Health Librarian. http://nnlm. gov/scr/conhlth/ethics.htm. (13 Jan 2005).

11. Rees A. The Librarian's role in the provision of consumer health and patient education. Bull Med Libr Assoc 1996;82(2):238-9.

12. Tardiff K. Concise guide to assessment and management of violent patients. Washington, DC: American Psychiatric Press; 1989.

13. Satcher D. (1999). Mental Health: A Report of the Surgeon General. http:// www.surgeongeneral.gov/library/mentalhealth/home.html. (3 Jan 2004).

14. Eberle ML. (2004). Caring for the Mind: Providing Reference Services for Mental Health Information. http://www.nnlm.gov/ner/consumer/caringforthemind. htm. (20 Dec 2004). 
15. Healthnet: Connecticut Consumer Health Information Network. (2001). Mental health resources: a guide for patients and families. http://library.uchc.edu/departm/ hnet/mentresource.html. (18 Dec 2004).

16. Hughes MA. The two faces of mental illness. Libr J 2004;129(8):49-52.

17. McMaster Children's Hospital Community Education Services. Books and resources for parents. http://www.communityed.ca/frames.htm?booklist.htm main. (14 Jan 2005).

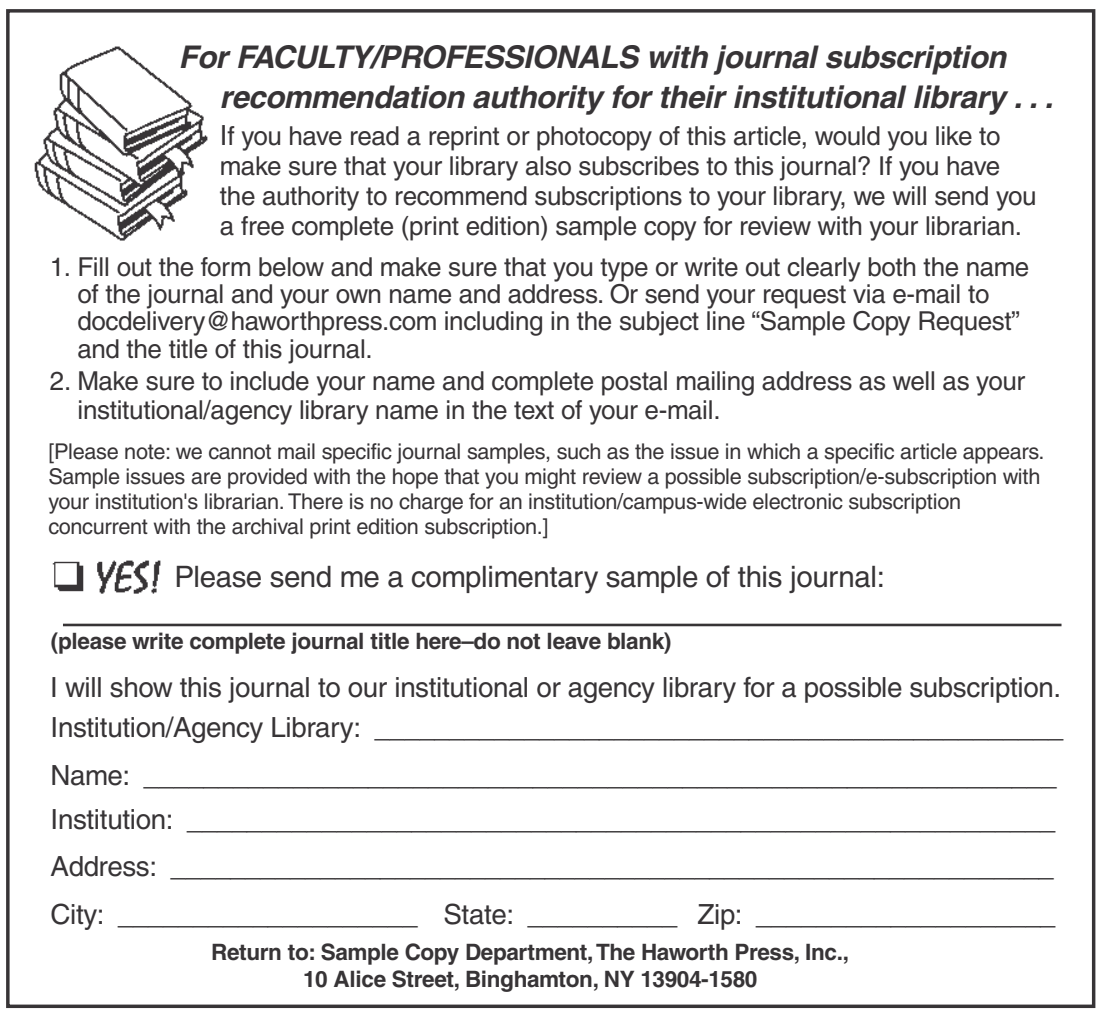

